\title{
LAST WORDS ON THE APPORTIONMENT PROBLEM
}

\author{
WaLter F. Wilicox*
}

This paper has been prepared in response to the editor's request for "a review of the methods of congressional reapportionment addressed to the average citizen not versed in mathematics." I am glad to comply with the request because within the last forty years a small group of scholars have developed what I believe to be an erroneous mathematical analysis of the problem and have persuaded Congress in reliance on that analysis to displace a better method by a poorer one. The debate during that period has been of great value, however, because it has cleared up many obscure points and suggests that the time has come for a new, possibly a final, exposition of the century-old problem.

The average citizen wants first some history of the question. That has been my own approach but one which of recent years has been neglected.

The ad interim House of Representatives set up by the Constitution to serve until after the first census had only 65 members. This number was based on that of its predecessor, the unicameral Continental Congress, limited to $9 \mathrm{r}$ members, 7 for each of the $\mathrm{r}_{3}$ states. When the new Constitution took 26 away from that Congress to make the new Senate, 65 remained for the House. These were apportioned among the states according to whatever population figures were available.

A House of only 65 members, however, was too small and before the first census it became evident that Congress would enlarge it up to the limit set by the Constitution, "not more than one for every thirty thousand." As the debate began, however, that limit was found to be ambiguous. Did it mean not more than one for every 30,000 in any state and so II2 in all, as the House claimed, or not more than one for every 30,000 in the country as a unit and so 120 , as the Senate interpreted the phrase? The Senate won its long struggle with the House only to lose in the end when Washington vetoed the bill in its Senate form as unconstitutional. That veto, the first ever sent to Congress, established what is now called the method of rejected fractions, used until I840.

The earliest apportionment bill as it left the House divided the population of each state by 30,000 and apportioned to it as many representatives as there were units in its quotient. Since the rejected remainders averaged about 15,000, a fraction

* A.B. I884, A.M. 1888, LL.D. I906, Amherst College; LL.B. 1887, Ph.D. I891, Columbia University. Member of the New York bar. Professor of Economics and Statistics, Cornell University, since 1892, now emeritus. Author, The Apportionment of Representatives (presidential address to the Amcrican Economic Association), 6 As. Econ. Rev. Supp. 3-r6 (1916); The Recent Apportionment in New York State, 2 CoRneli L. Q. I (1916); The Role of Mathematics in Congressional Apportionment: A Reply, 4 Sociometry 283 (1941); The Apportionment Problem and the Size of the House: $A$ Return to Webster, 35 Cornell L. Q. 367 (1950); Methods of Apportioning Seats Among the States in the American House of Representatives, 3 International Statistical Conferences Proceedings, 1947858 (1951). 
of each state's population would go unrepresented-in other words, the average district population in each state would exceed 30,000 and the smaller the state the larger the proportion which that excess population made of the total. If the excess population had been 15,000 in Delaware and Virginia, the smallest and largest states, it would have constituted 27 per cent of Delaware's population and only 2.4 per cent of Virginia's.

The four persons who had most to do with the adoption of this method were Virginians; Washington was persuaded by Jefferson, the Secretary of State, to veto a bill shaped by the Senate and based on another method. The reluctant President then asked Jefferson, Madison, and Randolph to join in writing a veto message for him to sign.

How little the mathematics of the problem was understood appears from the fact that in the lengthy House debate, ${ }^{1}$ there was no suggestion that the method adopted would favor the large states, especially Virginia, which then had about one-sixth of the country's population.

After the census of 1830 the House committee brought in a bill based on the method of rejected fractions and increasing the size of the House from 213 to 240 members, or 12 per cent. But the population of the country had increased nearly three times as fast and as a result Massachusetts along with three other states stood to lose a seat. The Massachusetts delegation under the leadership of John Quincy Adams fought vainly against the bill. After his defeat in the House Adams persuaded his colleague, Daniel Webster, to renew the fight in the Senate. Thereupon Webster lifted what had been an unimportant political quarrel into a grave constitutional issue by contending that the method of rejected fractions did not apportion representatives among the states "according to their respective numbers." He proposed to displace it by another method, that of major fractions, for which the Senate had vainly contended forty years before. Webster's method was designed to apportion an extra seat for each fractional remainder larger than onehalf. He stated in two ways what he called "a rule, plain, simple, just, uniform, and of universal application." But he had not mastered the mathematics of the problem and consequently neither statement would hold water. He wanted a method which would yield whatever number of representatives was required. His first statement was that "the whole number of the proposed House [in the bill before Congress this was 240] shall be apportioned among the several States according to their respective numbers, giving to each state that number of members which comes nearest to her exact mathematical part, or proportion. ..." His exposition shows that he meant to give an extra seat for every major fraction. New York, for example, which was entitled by computation to 38.59 seats would receive 39 and not 40 as the pending bill proposed. The trouble with this statement of the rule is that it would have yielded not 240 but $24 \mathrm{I}$ seats. His other statement was no better.

${ }^{1}$ Debates in the Senate were not then reported. 
He said, "The population of each State shall be divided by a common divisor, and $\ldots$ in addition to the number of members resulting from such division, a member shall be allowed to each State whose fraction exceeds a moiety of the divisor." the trouble was that no one knew how to find the "common divisor" which would yield the number of members needed. These weaknesses were not brought out in debate and in the end Webster's method was approved by the Senate but not by the House, and the Senate receded.

Ten years later, however, the Senate amended the House bill so as to apportion extra seats for fractions larger than one-half and the House yielded. The difficulties with the method as stated by Webster did not arise because Congress merely specified a divisor, not the total number of seats, and declared that an extra seat should be apportioned for every major fraction.

In $185^{\circ}$ Congress tried to stabilize the size of the House by authorizing the Secretary of the Interior after the approaching census to apportion 233 members, later increased to 234 by giving. California a second seat. Because neither of the old methods could be trusted to yield a specified result Congress instructed the Secretary to employ one called after the name of its chief sponsor in Congress, the Vinton method. It divided the total population of the states by the proposed number of representatives and then the population of each state by the quotient. The sum of the units in the quotients of course would fall short of 234. Additional seats were then to be apportioned to enough states with large fractional remainders to get the desired total. In $185^{\circ}$ the sum of the units was 220 and there proved to be just I4 fractions larger than .500 , for each of which an extra seat was apportioned. But by this method one or more states with remainders above .500 might fail to get extra seats or one or more with remainders below .500 might get them.

This method was retained after the r860 census but when the Civil War ended Congress returned to the policy of enlarging the House. Thereupon, the Superintendent of the Census began sending to Congress after a census tables apportioning each number of seats from the existing size up to one at which no state would lose a seat. They brought out a difficulty with the method called the Alabama paradox. As the size of the divisor decreased, the quotients for large states increased faster than those for small ones. When the membership was to be enlarged by one the remainders for two large states might pass that for a small one. After the 1880 census, if the size of the House had been increased from 299 to 300 , the remainders for Illinois and Texas would have passed that for Alabama, and Alabama would have lost a seat.

Congress avoided one of these difficulties by not choosing a size of House involving the Alabama paradox and the other by giving any state with a fraction above .500 an additional seat although the method did not allow it.

After the Igoo census each difficulty caused trouble. The debate showed that

\footnotetext{
2I Joseph Story, Commentaries on the Constitution of the United States $511-512$ n. (5th ed., Bigelow, t89x); Callie L. Bonney, The Wisdom and Eroquence of Daniel Wedster 127 (1886).
} 
Congress would like tables free from the Alabama paradox and not giving an additional seat for a minor fraction or withholding one for a major. After the rgro census, such tables developing Webster's idea into the major fraction method were laid before Congress, adopted for that apportionment, and retained until r940, when it was replaced by the method of equal proportions.

With this historical outline in mind the average citizen will be better able to grasp the following argument. Nothing within his experience is so like the problem of apportionment as that of measuring a person's age in years. An examination of that simple problem will open a way to the harder one.

The usual method of putting the age question is, age at last birthday or, in other words, age in completed years? A person 30 years and II months old would give his age as 30 years. Early apportionments measured representation in the same way, rejecting fractions of a representative.

Life insurance companies prefer another form of the question, age at nearest birthday? If this form is used, a person passes from one year of age to another half way between birthdays; in technical language the critical fraction or point at which one unit ends and another begins is one-half. In apportionment a fractional remainder smaller than one-half is rejected and a larger one entitles a state to another representative.

A third way of measuring age in years is used occasionally in answer to the question, age at next birthday or year of life? The age in years of a child less than six months old would be given as an answer to the question in its first or second form as zero years, but in its third form, as under one year or in the first year. In apportionment, the corresponding method is that of included fractions. One representative is assigned for any fraction, however small. In theory, any fraction between zero and one, like any day between birthdays, can be made the critical fraction or threshold value at which one unit, a year of life or a representative, passes into another.

The next step is to imagine a case including all the elements of an apportionment in the United States, but reducing them to their lowest terms. Cut down the number of states from 48 to $3, A, B$, and $C$, with a population of 3,000,000 divided as below:

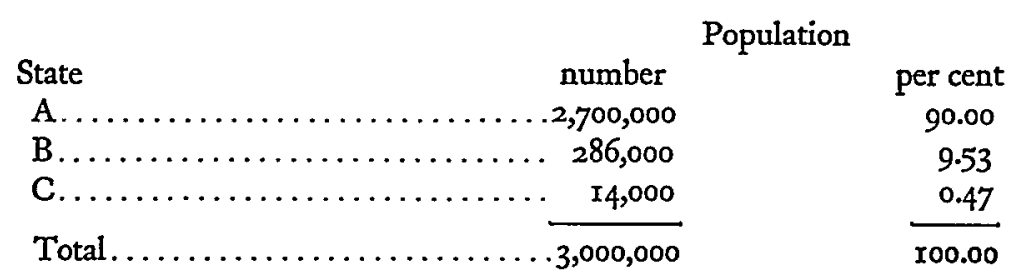

Reduce the number of representatives from 435 to roo, thus making the standard district population 30,000 but retain these provisions, "Representatives shall be apportioned among the several states according to their respective numbers," and "each state shall have at least one Representative." 
If our average citizen had been charged with writing an apportionment bill to meet these conditions, could he do better than to propose giving 89 seats to state $A$, Io to state $B$, and I to state $C$, based on the following procedure?

First, assign I seat to each state as the Constitution requires, then apportion 9 more seats to state $A$, at which point with ro seats its district population of 270,000 falls below the total population of state $B, 286,000$. At that point apportion a second seat to state $B$, followed by another series to state $A$, until its district population again falls below the new district population of state $B$, I43,000. Continue that procedure until 97 seats have been apportioned. These are the results:

\begin{tabular}{cccc}
\multicolumn{2}{c}{ Number of seats } \\
State & assigned & apportioned & total \\
A & I & 88 & 89 \\
B & $I$ & 9 & Io \\
C & I & 0 & I \\
Total & -3 & 97 & Ioo
\end{tabular}

$A$ gets I seat less than its population alone would give it, that loss being balanced with a gain of .47 of a seat by $B$ plus .53 by $C$.

The argument for this method might be, propose a fairer rule than to give seat after seat to whatever state then has the largest district population until the 97 apportionable seats have been apportioned; or, it might be asked, does any other result come nearer to apportioning seats among the several states according to their respective numbers?

After these preliminaries we are better prepared, I hope, to examine the real problem.

Four methods are to be considered, two extreme ones-rejected fractions and included fractions-two intermediate ones-major fractions and equal proportions.

Three of these methods, rejected fractions, major fractions, and included fractions, are easily understood; the method of equal proportions is explained in a recent article by Professor Chafee which advocates it. ${ }^{3}$ Its results after the ${ }^{7} 7$ censuses agree with those of the method of major fractions in 9 cases; in the other 8 they would differ by a total of Io seats.

The method of rejected fractions was abandoned after it had been used for half a century; the methods used since then apportion additional seats for fractions of one-half or nearly that. A fundamental difference between the methods of major fractions and equal proportions is that the former adopts an unchanging critical fraction, 500 , while the latter adopts a changing one always lying between $.4 \mathrm{~T} 4$ and .500 . This fraction increases with the number of seats a state receives. The difference explains why, when the results of the two methods disagree, the method of equal proportions gives the seat in question to the smaller state, e.g., Arkansas rather than Michigan after 1940, Kansas rather than California after 1950. The

${ }^{3}$ Chafee, Rapportionment of the House of Representatives Under the 1950 Census, 36 Connelz L. Q. 643 (1951). 
TABLE I

Apportionment of 435 Representatives Under I950 Figures by Method of

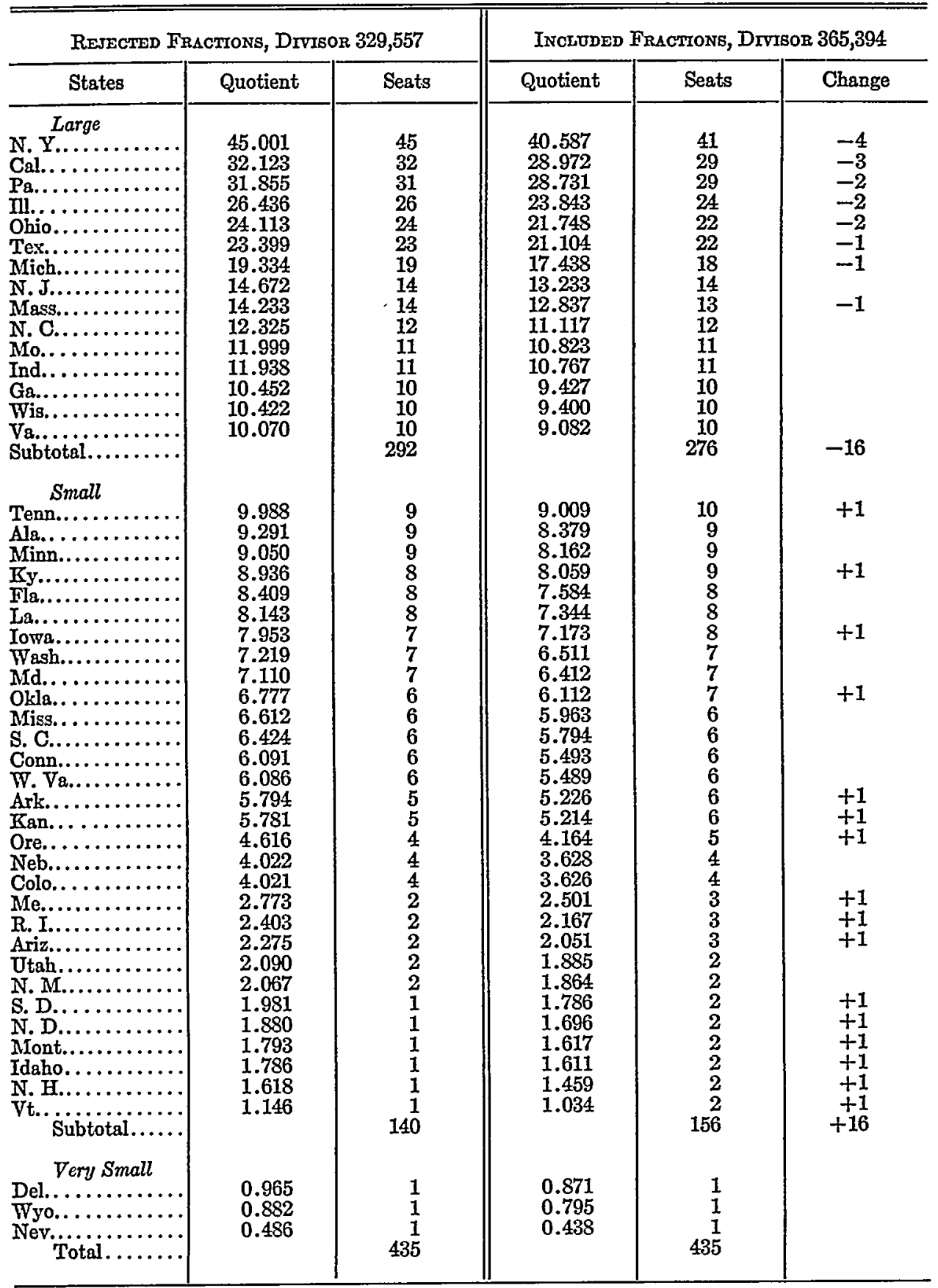


mathematicians will see that this difference is due to the fact that the method of major fractions uses the arithmetic mean and that of equal proportions the geometric mean as the critical fraction. One who wishes to examine the arguments in favor of the geometric mean and the method of equal proportions should study Professor Chafee's article, already cited.

Table I shows that after the $195^{\circ}$ census there were 16 "transferable seats" all

TABLE II

Apportionment of 435 Representatives Under I950 Figures by Method of

\begin{tabular}{|c|c|c|c|c|c|}
\hline \multicolumn{3}{|c|}{$\begin{array}{l}\text { Major Fractions, Drvisor } 346,801 \\
\text { Critical Fraction } .500\end{array}$} & \multicolumn{3}{|c|}{$\begin{array}{c}\text { Equal Proportions, Divisor } 347,300 \\
\text { Crit ical Fraction } .485\end{array}$} \\
\hline State & Quotient & Seats & State & Quotient & Seats \\
\hline 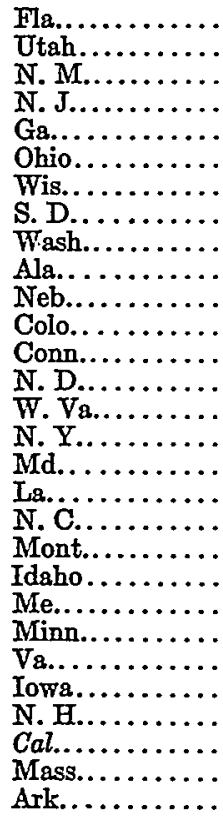 & $\begin{array}{r}7.991 \\
1.986 \\
1.964 \\
13.943 \\
9.932 \\
22.914 \\
9.904 \\
1.882 \\
6.860 \\
8.829 \\
3.822 \\
3.821 \\
5.788 \\
1.787 \\
5.783 \\
42.763 \\
6.756 \\
7.738 \\
11.713 \\
1.704 \\
1.697 \\
2.635 \\
8.600 \\
9.569 \\
7.558 \\
1.538 \\
30.525 \\
13.525 \\
5.506\end{array}$ & $\begin{array}{r}8 \\
2 \\
2 \\
14 \\
10 \\
23 \\
10 \\
2 \\
7 \\
9 \\
4 \\
4 \\
6 \\
2 \\
6 \\
43 \\
7 \\
8 \\
12 \\
2 \\
2 \\
3 \\
9 \\
10 \\
8 \\
2 \\
31 \\
14 \\
6\end{array}$ & 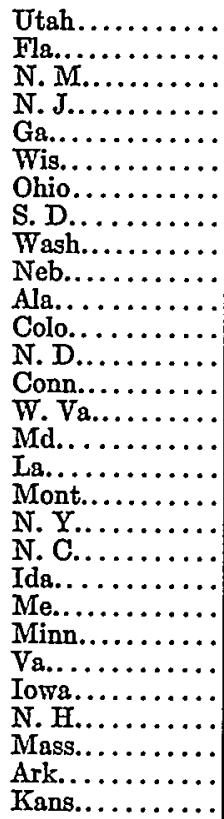 & $\begin{array}{r}1.983 \\
7.980 \\
1.961 \\
13.923 \\
9.918 \\
9.889 \\
22.881 \\
1.879 \\
6.850 \\
3.817 \\
8.816 \\
3.815 \\
1.784 \\
5.780 \\
5.775 \\
6.746 \\
7.727 \\
1.702 \\
42.701 \\
11.696 \\
1.695 \\
2.531 \\
8.588 \\
9.556 \\
7.547 \\
1.535 \\
13.506 \\
5.498 \\
5.486\end{array}$ & $\begin{array}{r}2 \\
8 \\
2 \\
14 \\
10 \\
10 \\
23 \\
2 \\
7 \\
4 \\
9 \\
4 \\
2 \\
6 \\
6 \\
7 \\
8 \\
2 \\
43 \\
12 \\
2 \\
3 \\
9 \\
10 \\
8 \\
2 \\
14 \\
6 \\
6\end{array}$ \\
\hline 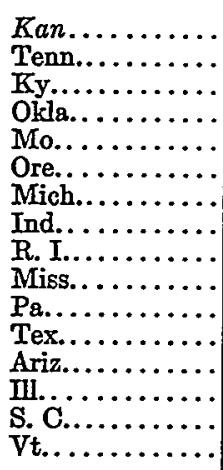 & $\begin{array}{r}5.494 \\
9.492 \\
8.491 \\
6.440 \\
11.403 \\
4.387 \\
18.373 \\
11.344 \\
2.283 \\
6.283 \\
30.271 \\
22.235 \\
2.161 \\
25.122 \\
6.104 \\
1.089\end{array}$ & $\begin{array}{r}5 \\
9 \\
8 \\
6 \\
11 \\
4 \\
18 \\
11 \\
2 \\
6 \\
30 \\
22 \\
2 \\
25 \\
6 \\
1\end{array}$ & 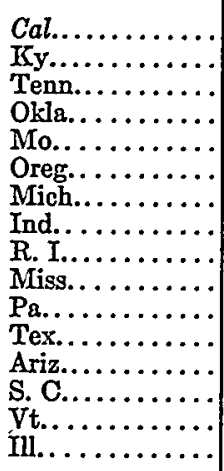 & $\begin{array}{r}30.481 \\
8.479 \\
9.478 \\
6.431 \\
11.387 \\
4.380 \\
18.347 \\
11.328 \\
2.280 \\
6.274 \\
30.228 \\
22.203 \\
2.158 \\
6.096 \\
1.088 \\
25.085\end{array}$ & $\begin{array}{r}30 \\
8 \\
9 \\
6 \\
11 \\
4 \\
18 \\
11 \\
2 \\
6 \\
30 \\
22 \\
2 \\
6 \\
1 \\
25\end{array}$ \\
\hline
\end{tabular}


of which the method of rejected fractions would allot to large states and that of included fractions would allot to small ones. It shows also that three-fourths of the transfers occur among $\mathrm{I} 7$ of the 45 states, those lying near extremes of population, Ohio and above, Arkansas and below. It also suggests what mathematical analysis proves that a series of 15 divisors falling between 329,557 and 365,394 can be found, such that the $1_{5}$ divisions combined with critical fractions of proper size will yield results each differing from its neighbors on either side by transferring a single seat from one group to the other.

This is illustrated by Table II in which two intermediate divisors shift, of the 16 transferable seats, 8 under the method of major fractions, and 9 under that of equal proportions, from the group of large to that of small states, major fractions giving a seat to California which equal proportions gives to Kansas. The critical fraction lies at whatever point between .414 and .500 is needed to apportion 435 seats. Under $195^{\circ}$ conditions it is 485 ; under those of $194^{\circ}$ it is $.45^{\circ}$. One can amuse himself, as I have done, and at the same time get a firmer grip on the problem by selecting by trial and error the divisors needed to get various other intermediate results.

TABLE III

Apportionment of 270 Representatives UNDER I950 Figures by Method of

\begin{tabular}{|c|c|c|c|c|}
\hline State & $\begin{array}{l}\text { Rejected } \\
\text { Fractions }\end{array}$ & $\begin{array}{l}\text { Major } \\
\text { Fractions }\end{array}$ & $\begin{array}{c}\text { Equal } \\
\text { Proportions }\end{array}$ & $\begin{array}{l}\text { Included } \\
\text { Fractions }\end{array}$ \\
\hline 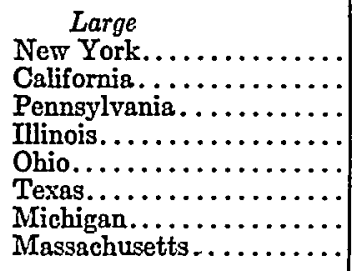 & $\begin{array}{l}45 \\
32 \\
31 \\
26 \\
24 \\
23 \\
19 \\
14\end{array}$ & $\begin{array}{l}43 \\
31 \\
30 \\
25 \\
23 \\
22 \\
18 \\
14\end{array}$ & $\begin{array}{l}43 \\
30 \\
30 \\
25 \\
23 \\
22 \\
18 \\
14\end{array}$ & $\begin{array}{l}41 \\
29 \\
29 \\
24 \\
22 \\
22 \\
18 \\
13\end{array}$ \\
\hline Total.............. & 214 & 206 & 205 & 198 \\
\hline 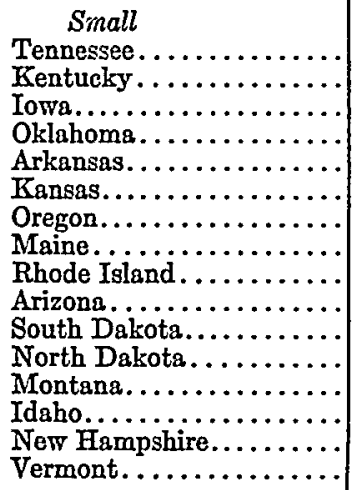 & $\begin{array}{l}9 \\
8 \\
7 \\
6 \\
5 \\
5 \\
4 \\
2 \\
2 \\
2 \\
1 \\
1 \\
1 \\
1 \\
1 \\
1\end{array}$ & $\begin{array}{l}9 \\
8 \\
8 \\
6 \\
6 \\
5 \\
4 \\
3 \\
2 \\
2 \\
2 \\
2 \\
2 \\
2 \\
2 \\
1\end{array}$ & $\begin{array}{l}9 \\
8 \\
8 \\
6 \\
6 \\
6 \\
4 \\
3 \\
2 \\
2 \\
2 \\
2 \\
2 \\
2 \\
2 \\
1\end{array}$ & $\begin{array}{r}10 \\
9 \\
8 \\
7 \\
6 \\
6 \\
5 \\
3 \\
3 \\
3 \\
2 \\
2 \\
2 \\
2 \\
2 \\
2\end{array}$ \\
\hline Total.............. & 56 & 64 & 65 & 72 \\
\hline
\end{tabular}


Table III above gives the results of apportionment by each of the 4 methods for the 24 states in which with r950 figures changing the method would change the distribution.

The choice of a method turns upon the objective. If it is to give as many seats as possible to the big states, the method of rejected fractions is best; if it is to give as many seats as possible to the small states, the method of included fractions is best; if it is to hold the.balance between the two groups, both extreme methods are ruled out in favor of an intermediate one. The test by which to determine which method best holds that balance is to ask which comes nearest to equalizing the district populations of the two groups. The results would differ in only 8 censuses out of the $I 7$ since $I 790$; in every one of them the method of major fractions comes off best. For example, a computation based on $195^{\circ}$ figures yields this result.

\begin{tabular}{|c|c|c|}
\hline & $\begin{array}{c}\text { District } \\
\text { equal } \\
\text { proportions }\end{array}$ & $\begin{array}{l}y \text { method of } \\
\text { major } \\
\text { fractions }\end{array}$ \\
\hline \multirow{2}{*}{$\begin{array}{l}\text { I5 large states. } \\
30 \text { small states. }\end{array}$} & $\cdots 347,45^{8}$ & 346,235 \\
\hline & $\cdots 340,912$ & 343,215 \\
\hline Difference .... & . 6,546 & 3,020 \\
\hline
\end{tabular}

A mathematician will see at once that a critical fraction of .500 must hold the balance better than the smaller critical fraction adopted by the method of equal proportions.

Early in the present century the problem was attacked along a new line. Before I9Io a start was made by dividing the population of each state by the standard district population or ratio and then apportioning seats either for every unit in the quotient or for every such unit and for enough fractions to yield the desired total. After this had been done the constitutional provision entered to give seats to states still without representation.

This procedure made the constitutional seats seem like a pendant to the apportioned ones.

It is now realized that the Constitution sets both an upper limit on the size of the House ("not more than one to every thirty thousand") and a lower one ("Each state shall have at least one Representative"). The first step towards the change was taken when attention was called to "the crucial fact that seats in the House of Representatives are of two classes, the 48 , one for each state, which are guaranteed by the Constitution and are as completely beyond the control of Congress as seats in the Senate are and the remainder, the number and distribution of which are under congressional control."4

All students now agree that apportionment by Congress starts, not with a clean slate, but with these 48 constitutional representatives unrelated to population. It follows, as corollaries, first, that in every distribution of seats two methods are in-

-Willcox, The Apportionment of Representatives, 6 AM. Econ. Rev. Supp. 3-16 (1916). 
TABLE IV

District Population Under ig5o Population by Three Methods of Apportionment

\begin{tabular}{|c|c|c|}
\hline $\begin{array}{c}\text { Past Method } \\
\text { Rejected Fractions }\end{array}$ & $\begin{array}{l}\text { Present Method } \\
\text { Equal Proportions }\end{array}$ & $\begin{array}{l}\text { Proposed Method } \\
\text { Included Fractions }\end{array}$ \\
\hline 160,083 & 160,083 & Nevada. \\
\hline yoming........... & New Hampshire... & 188,873 \\
\hline elaware........... & Wyoming......... & $.247,862$ \\
\hline New York......... & Idaho..... & Rhode Island. . . . \\
\hline California......... & Montana. . & New Hampshire... \\
\hline Ohio.............. & Maine ...... & yoming........ \\
\hline Colorado.......... & North Dakota.... . & daho............ \\
\hline Jebraska.......... & Kansas........... & ontans........ \\
\hline Minnesota.......... & Jelaware.......... & 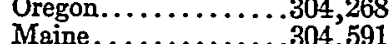 \\
\hline $\begin{array}{l}\text { Virginia. ..............331,868 } \\
\text { West Virginia. . . . . . . } 334,259\end{array}$ & 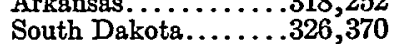 & North Dikota.... \\
\hline Connecticut......... & Iowa............327,634 & Kansas........... \\
\hline Maryland . . . . . . . & Colorado. . & Delaware......... \\
\hline Massachusetts..... & $.331,378$ & Arkansas. . . . . . \\
\hline Illinois. . . . . . . . . . & Minnesota. & South Dakota. . \\
\hline $.335,269$ & Virginia. . $\ldots$. & Kentucky...... \\
\hline Michigan.......... & West Virginis. . & Iowa........... \\
\hline Louisians........... & Connecticut... & Tennessee....... \\
\hline North Carolina..... . & Maryland . ..... & Colorado........ \\
\hline Pennsylvania. . . . . . & achusetts. . & Tebraska. . \\
\hline Washington........ & Louisiana........ . & Minnesots...... \\
\hline Alabama. . . . . . . . . & h Carolina... & Virginia......... \\
\hline Wisconsin.......... & Washington...... & Oklahoms....... \\
\hline 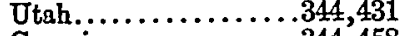 & Alabama...... & West Virginia... \\
\hline Georgia. ...........344 & 343,458 & anecticut. ..... \\
\hline $\begin{array}{l}\text { New Mexico. . . . . . . } 344,544 \\
\text { New Jersey. . . . . . .345,381 }\end{array}$ & $\begin{array}{l}.344,431 \\
.344,458\end{array}$ & $\begin{array}{l}\text { ryland. . . . . . . } \\
\text { disiana........ }\end{array}$ \\
\hline Florida.......... 346,413 & New Mexico..... & Washington......... \\
\hline South Carolina...... & New York...... & Alabama....... \\
\hline Indiana. . . . . . . . . & Jersey... & New Mexico.... \\
\hline Missouri . . . . . . . . & 345,506 & Wisconsin..... \\
\hline Mississippi. ........ & da.... & Utah.: \\
\hline Tennessee.... & Illinois... & Georgia..... \\
\hline Kentuoky .......... & Pennsylvania & Jersey... \\
\hline Oklahoma......... & $\ldots \ldots \ldots$ & Florida....... \\
\hline Iowa.............. & South Carolina & Te \\
\hline Árizona. . . . & California. & South Carolins.. \\
\hline Vermont. . & Michigan. & Michigan....... \\
\hline Oregon..... & Indiana. . & 357,657 \\
\hline 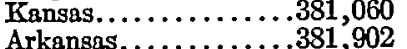 & 359 & $\begin{array}{l}\text { North Carolina. } \\
\text { Missouri. . . . . }\end{array}$ \\
\hline $\begin{array}{l}\text { Arkansas............ } \\
\text { Rhode Island....... }\end{array}$ & $\begin{array}{l}.363,152 \\
.365,746\end{array}$ & $\begin{array}{l}\text { Missour..... } \\
\text { Massachusett: }\end{array}$ \\
\hline $\begin{array}{l}\text { Rhode Lsland...... } \\
\text { Maine ........... }\end{array}$ & $.368,101$ & $.361,210$ \\
\hline New Hampshire... & Oklahoma...... & New York.... \\
\hline daho $\ldots \ldots \ldots \ldots \ldots$ & $.374,794$ & Pennsylvania. . \\
\hline Montana. . & Vermont... & Illinois... \\
\hline North Dakota... & .380 & Mississippi. . \\
\hline South Dakota.......652,740 & Rhode Island. . ..... & California.........365,042 \\
\hline & & \\
\hline Range... & & \\
\hline Median, . . . . . . 444,440 & & \\
\hline
\end{tabular}

volved, an assignment by the Constitution unrelated to population and an apportionment by Congress based on population and second, that the task in apportionment is to adopt a method which will add seat after seat to the original 48 in such a way that each seat apportioned shall reduce as much as possible the inequality then existing among the states. 
A citizen can best understand the four methods by following them as they apportion the first few seats in the House. All methods give seat No. 49 to New York, seat No. $5^{\circ}$ to California, and seat No. 5 I to Pennsylvania. Seat No. 52, however, is given by the methods of rejected fractions and major fractions to New York, but by the methods of equal proportions and included fractions to Illinois. Since Illinois with one seat has a larger district population than New York with two, giving the seat to Illinois will reduce the inequality but giving it to New York will not. This entails discarding the methods of rejected fractions and major fractions. The next seat, No. 53, is given by the method of equal proportions to New York and by that of included fractions to Ohio. Since Ohio with one seat has a larger district population than New York with two, giving it to Ohio will reduce the inequality while giving it to New York will not. This process of elimination leaves only the method of included fractions.

Table IV above shows the results of apportionments by three of the four methods examined.

The methods of major fractions and equal proportions have a common aim, namely, to equalize the district population of the two groups of large and small states; as has been shown, the results of the method of major fractions come nearer that mark.

The method of included fractions has a different aim-to equalize the district populations of the 48 states. A method with that aim would enable a congressman to declare with truth that each member of the House represents as nearly the same number of people as the mathematical conditions of the problem and the vagaries or negligences of state legislatures permit.

The figures in Table IV are given graphic expression in the diagram.

The diagram shows that the difference between columns 2 and 3 is like that between $I$ and 2, but much less.

The figures at the bottom of Table IV show that under the method of included fractions, the average district population would be less than under the present method just as under the present method it is less than it would be under the past.

The diagram suggests that the problems now before Congress and the public are:

(x) Is the present method of equal porportions better adapted than that of major fractions to reach the common aim? That question the experts can help with.

(2) Is either of these methods better than the method of included fractions? That question is for Congress, because an answer to it turns on the interpretation of the constitutional requirement, "according to their respective numbers." 


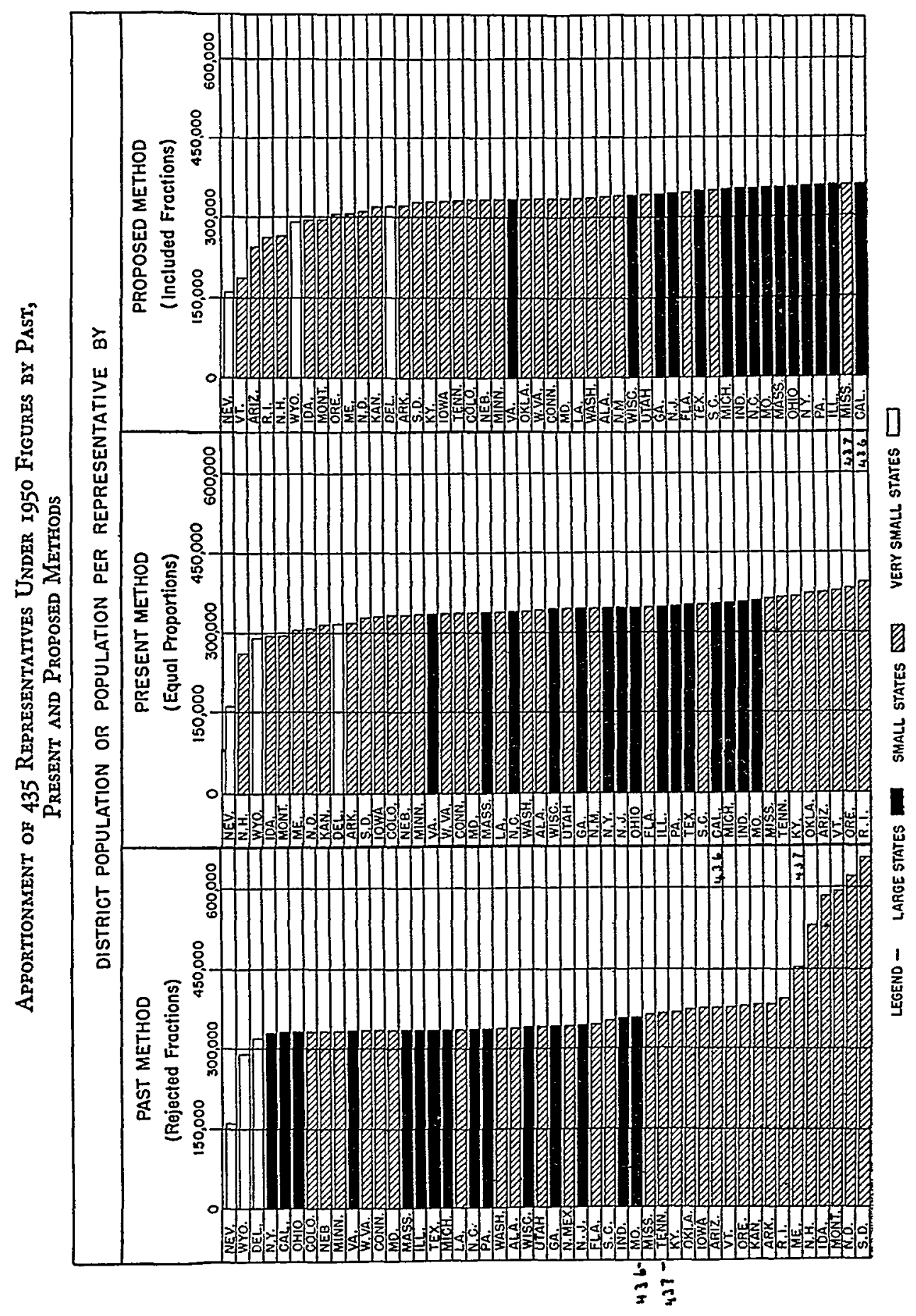

